dr hab. inz. Marian Medwid prof. nadzw.

dr inj. Rafat Cichy

mgr inz. Wojciech Jakuszko

Instytut Pojazdów Szynowych ,TABOR”

\title{
Modelowanie kolumnowej struktury szynowego ukladu jezdnego na przykładzie maszyny roboczej typu „MERLO”
}

\begin{abstract}
$W$ artykule przedstawiono rezultaty prac koncepcyjnych prowadzonych $w$ Instytucie nad przystosowaniem wielofunkcyjnej maszyny budowlanej do jazdy po torach kolejowych. Zaprezentowano kilka wariantów koncepcji innowacyjnego, kolumnowego, szynowego ukladu jezdnego, oraz schematy hydraulicznego sterowania szynowego układu jezdnego z wykorzystaniem hydrauliki siłowej zabudowanej $w$ maszynie budowlanej. Przedstawiono przyktad zabudowy wybranego wariantu szynowego uktadu jezdnego oraz urzqdzeń pociagowo - zderznych pozwalajacych na wykorzystanie maszyny jako pojazdu trakcyjnego do przetaczania wagonów.
\end{abstract}

\section{Wstęp}

Pojazdy szynowo - drogowe to pojazdy przystosowane do poruszania się po drogach kołowych i torach trakcji kolejowej, tramwajowej i metra. Obecnie istnieje duża liczba różnego rodzaju pojazdów przystosowanych do tego typu pracy (ciagniki, czyszczarki, pojazdy ratownicze, pojazdy do zaopatrywania $\mathrm{w}$ paliwo, itp.), wyposażonych w różnorodne układy umożliwiające poruszanie się po torach. Ich budowę omówiono $\mathrm{w}[1,4,6]$. Układy jezdne tych pojazdów były również przedmiotem publikacji $[1,2,5]$ i są chronione wieloma patentami.

Analizowanym przykładem jest teleskopowa ładowarka obrotowa Merlo typu ROTO 33.13. Często jest wykorzystywana do prowadzenia prac budowlanych związanych $\mathrm{z}$ podawaniem palet $\mathrm{z}$ materiałami budowlanymi. Istnieje również możliwość wyposażenia urządzenia w elementy koparki, rozszerzając możliwości pracy maszyny. Zwarta zabudowa oraz ograniczenie miejsca na podwoziu przez zamontowanie tam urządzeń związanych z podstawową pracą ładowarki zmusiły do poszukiwania nowych rozwiązań konstrukcyjnych szynowego układu jezdnego.

W niniejszej publikacji zaprezentowano zespoły i mechanizmy, które są związane z jazdą ładowarki po torze kolejowym. Dodatkowe wyposażenie ładowarki, które ją przekształca w pojazd szynowo drogowy to:

- układ jezdny przedni,

- układ jezdny tylny,

- układ hydrauliczny sterowania rolkami jezdnymi,

- urządzenie pociągowo - zderzne.

\section{Opis techniczny}

W tabeli 1 przedstawiono charakterystyki pojazdu szynowo - drogowego. W części pierwszej przedstawiono dane, które są skrótowym wyciagiem parametrów technicznych ładowarki, w stanie przed przebudową, znajdujące się w karcie katalogowej. W części drugiej zaprezentowano parametry pojazdu, które będzie on posiadał podczas poruszania się po torze, oraz parametry związane z pracą pojazdu na torze. W części trzeciej pokazano parametry układu hydraulicznego podnoszenia i opuszczania rolek. W części czwartej porównano masy ładowarki w stanie podstawowym, oraz mase ładowarki po przerobieniu na pojazd szynowo - drogowy. Ładowarka MERLO po przebudowie na pojazd szynowo - drogowy zyskuje nie tylko możliwość poruszania się po torze i wykonywanie prac do których była przeznaczona jako pojazd drogowy, ale również możliwość pracy jako urządzenie do prac manewrowych na torach. Możliwość poruszania się po drogach i torach daje ładowarce znaczną przewagę nad tradycyjnymi lokomotywami, które dotychczas wykonywały te zadania.

\section{Opis budowy i działania}

Pojazd szynowo-drogowy (rys. 1) jest przystosowany do poruszania się po drogach i szynach trakcji kolejowej. Pojazd jest przeznaczony głównie do prac przeładunkowych oraz ziemnych. Dodatkowo może służyć do przetaczania wagonów w wagonowniach jak i do prac manewrowych na bocznicach. Pojazd umożliwia jazdę po torach o rozstawie wewnętrznym $1435 \mathrm{~mm}$ dzięki zastosowaniu kolumnowego szynowego układu jezdnego. 
Tabela 1

Dane charakterystyczne

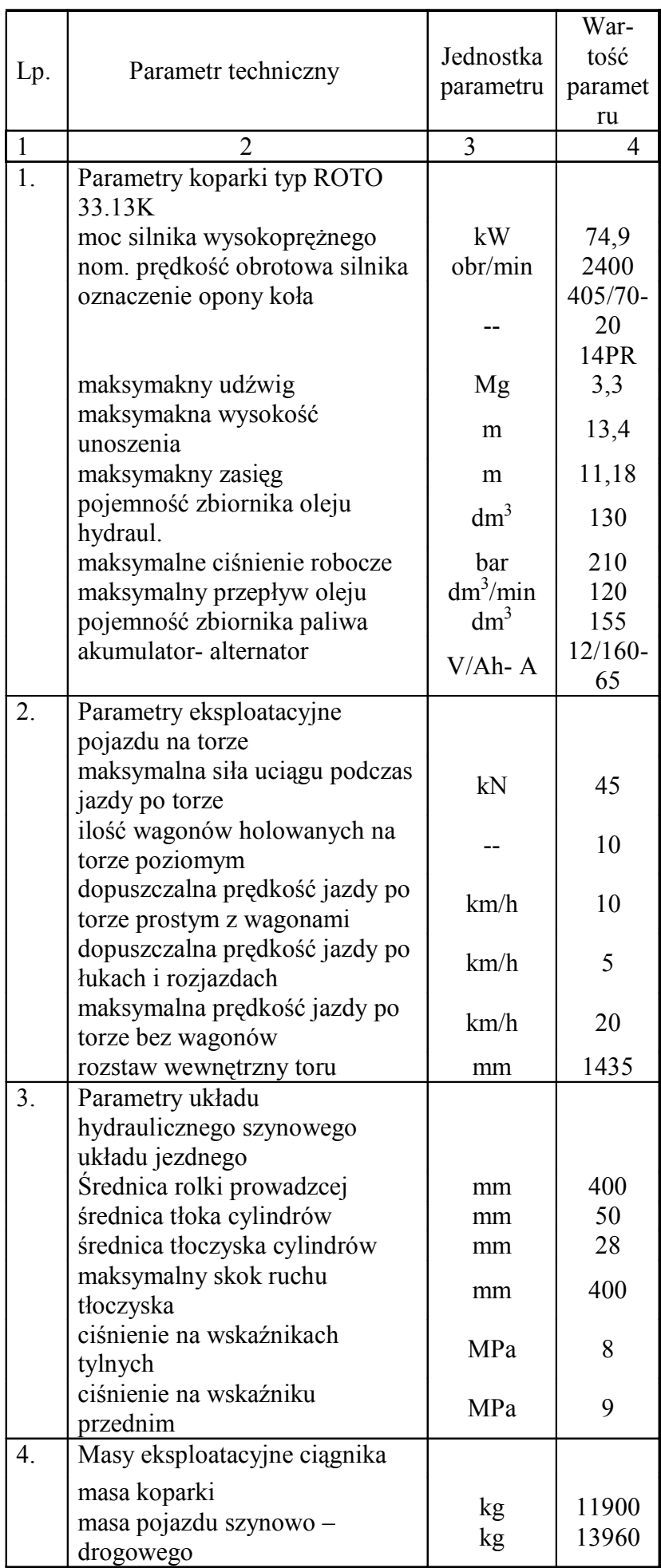

Wybrana koncepcja jest wynikiem szerokiej analizy różnorodnych rozwiązań konstrukcyjnych.

Analiza wykazała konieczność zastosowania układu jezdnego usytuowanego na zewnątrz ramy nośnej pojazdu. Cechy takiego rozwiązania charakteryzuje łatwy montaż i dostępność w czasie awarii, jednak charakter pracy uwzględniający obrotowy ruch teleskopowego wysięgnika ogranicza znacznie możliwości konstrukcyjne zabudowy szynowego układu jezdnego.
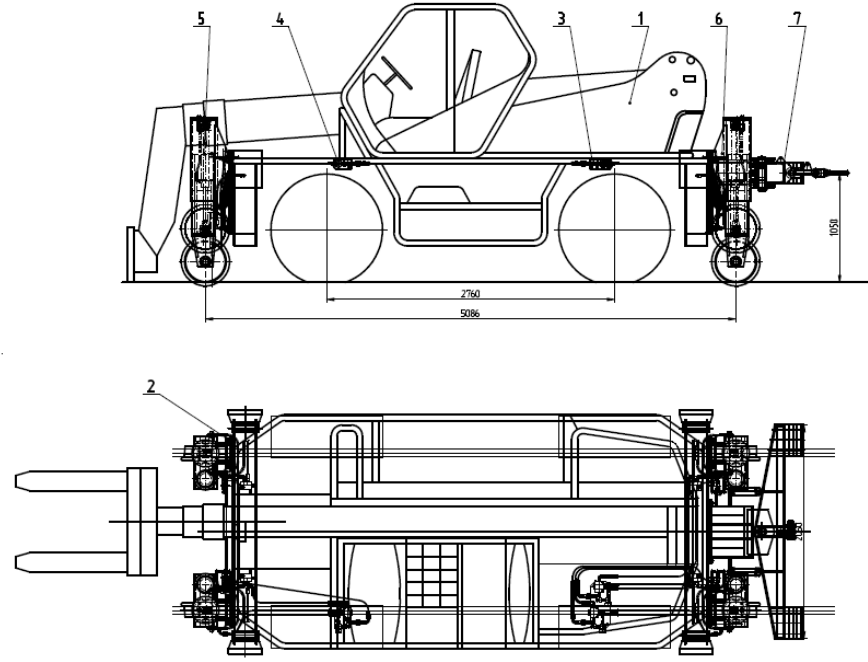

Rys. 1 Ładowarka szynowo - drogowa

W dalszej części artykułu przedstawiono warianty rozwiązań które były przedmiotem analiz podczas projektowania szynowego układu jezdnego ładowarki.

Koparka szynowo-drogowa jest wyposażona w następujące urządzenia i mechanizmy:

- koparka „Merlo” typu Roto 33,13K (1),

- układ hydrauliczny podnoszenia, opuszczania i docisku rolek (2),

- blok zaworów sterujących tylnych (3),

- blok zaworów sterujących przednich (4),

- układ jezdny przedni (5),

- układ jezdny tylny (6),

- układ pociagowo - zderzny (7).

\subsection{Wariant I}

Układ jest złożony z czterech niezależnych rolek, czterech siłowników, oraz $\mathrm{z}$ czterech kolumn prowadzących o przekroju prostokątnym (rys. 2). Każda kolumna jest utworzona $\mathrm{z}$ kolumny zewnętrznej 1 oraz wewnętrznej 2 do której jest zamocowana rolka prowadząca pojazd w torze 3 za pomocą osi 4 oraz łożysk tocznych 5 . Kolumnę zewnętrzną $1 \mathrm{w}$ górnej strefie wyposażono w czop 6 do którego zamocowano cylinder hydrauliczny 7 . Tłoczysko 8 cylindra połączono z uchami wspornika 9 związanego z kolumną wewnętrzną 2. Kolumna zewnętrzna 1 jest zamocowana do płyty 10 ramy nośnej pojazdu za pomoca połączenia sworzniowego 11 łączącego wsporniki 12 kolumny zewnętrznej z płytą 10 . Prostokątny przekrój poprzeczny kolumny zewnętrznej i wewnętrznej stanowią zabezpieczenie przed obrotem względem pionowej osi rolki prowadzącej pojazd w torze. Podnoszenie, opuszczanie i docisk rolki prowadzącej do szyny realizuje siłownik hydrauliczny zamocowany z boku kolumny. Wadą tego rozwiązania jest mimośrodowe działanie siły docisku rolki prowadzącej w stosunku do pionowej osi kolumny. Aby zagwarantować prawidłowe działanie układu należy zapewnić odpowiednio długie prowadzenie kolumny 
wewnętrznej w kolumnie zewnętrznej eliminując ewentualne zakleszczenie układu.

a)

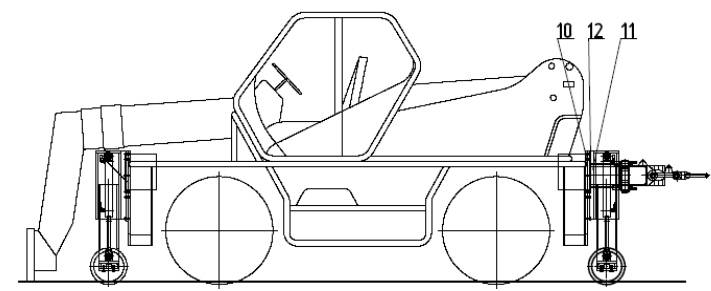

b)

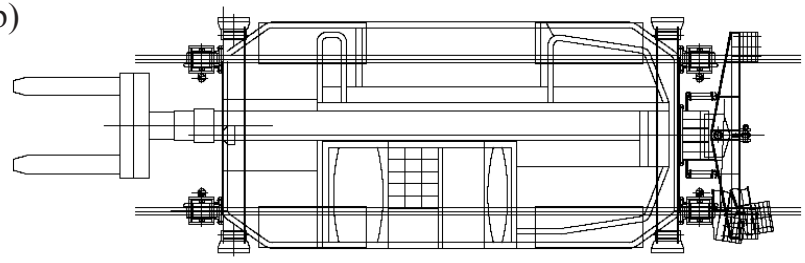

c)

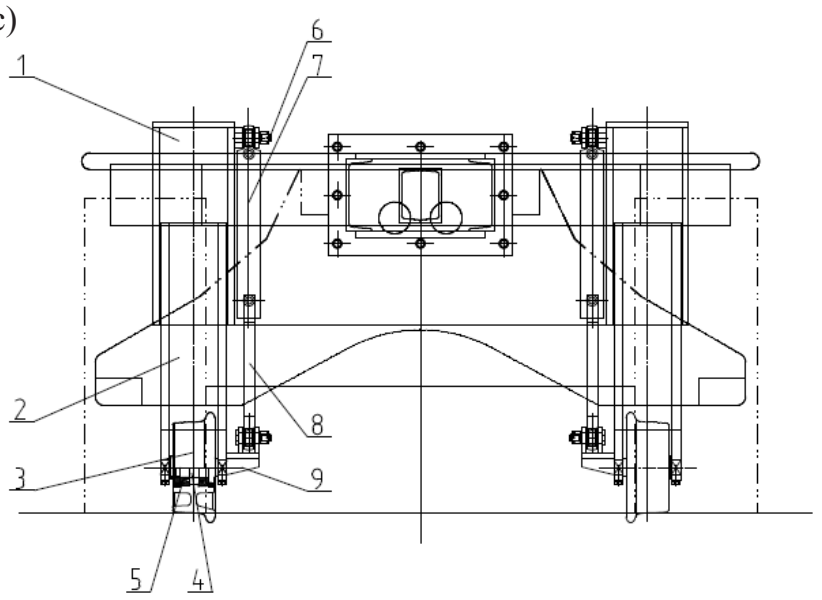

Rys. 2 Wariant I ładowarki szynowo drogowej

a) Widok $z$ boku b) Widok $z$ góry c) Widok $z$ tyłu

\subsection{Wariant II}

W drugim wariancie analizowanych koncepcji zastosowano kolumny zewnętrzne 1 oraz kolumny wewnętrzne 2 o okragłym przekroju poprzecznym (rys. 2). Okragły przekrój kolumn jest korzystny w odniesieniu do kolumn prostokątnych ze względów technologicznych i kosztu wytwarzania ponieważ do ich wykonania można wykorzystać znormalizowane rury. Zabezpieczenie przed obrotem kolumny wewnętrznej względem kolumny zewnętrznej zrealizowano za pomoca prowadnika 3 przytwierdzonego do wspornika 4 związanego z kolumną wewnętrzną 2 . Prowadnik 3 przemieszcza się suwliwie w kierunku pionowym w tulei 5 zamocowanej do kolumny zewnętrznej. Siłownik hydrauliczny 6 umieszczono wewnątrz kolumn w ten sposób, że cylinder siłownika połączono za pomocą sworznia z wspornikami 7 płyty górnej kolumny zewnętrznej a ucho tłoczyska $\mathrm{z}$ wspornikiem 8 związanym z kolumną 2.

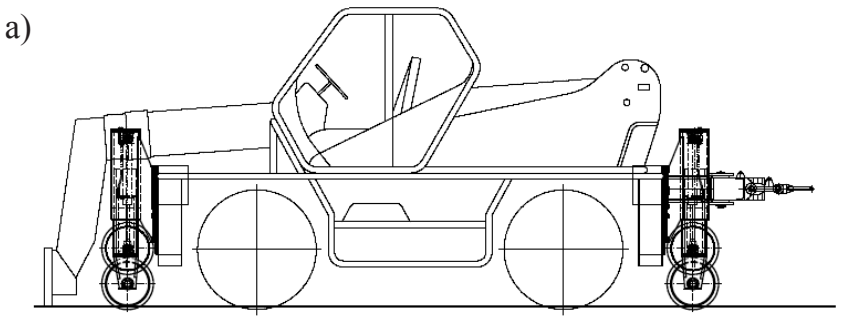

b)

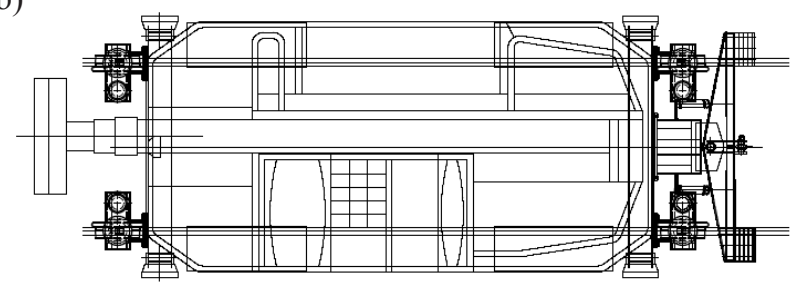

c)

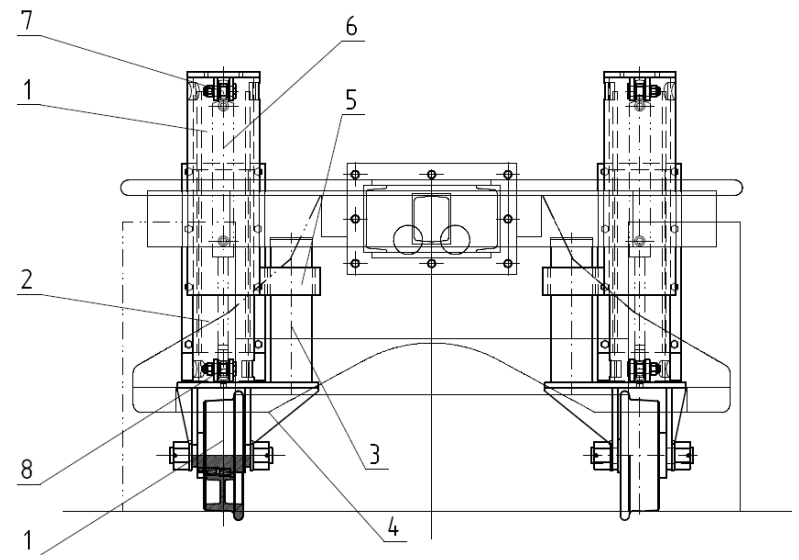

Rys. 3 Wariant II ładowarki szynowo drogowej

a) Widok $z$ boku b) Widok z góry c) Widok z tyłu

\subsection{Wariant III}

W trzecim wariancie zastosowano kolumny 1 o prostokątnym przekroju poprzecznym oraz po dwa siłowniki hydrauliczne 2 dla każdej kolumny (rys. 4). Siłowniki hydrauliczne 2 umieszczono na zewnattrz kolumny symetrycznie po obu stronach. Ucha 3 cylindrów zamocowano do wsporników usytuowanych $\mathrm{w}$ górnej strefie kolumny zewnętrznej a ucha toczysk 4 połączono z wspornikami 5 przyspawanymi do ścian bocznych kolumny wewnętrznej 6 . W ścianach bocznych kolumny wewnętrznej zamocowano również oś 7 rolki prowadzącej 8 ułożyskowanej na osi za pomocą odpowiednich łożysk tocznych 9.

$\mathrm{Na}$ rysunku 5 przedstawiono odmianę zabudowy kolumn według wariantu III z połączeniem kolumn wewnętrznych łącznikiem sprężystym ustalającym rozstaw poprzeczny rolek prowadzących i zabezpieczających obrót kolumn wewnętrznych względem osi pionowej $\mathrm{w}$ ramach istniejących luzów między kolumnami wewnętrznymi i zewnętrznymi.

W tym przypadku można zastosować tańsze kolumny o kołowym przekroju poprzecznym. Opuszczanie i podnoszenie rolek prowadzących za pomoca dwóch siłowników hydraulicznych obsługujących 
jedną kolumnę wymaga zastosowania synchronizacji pracy obu siłowników przez równomierne doprowadzenie oleju do ich zasilania. Bardziej szczegółowo kolumnowy szynowy układ jezdny zaprezentowano w punkcie 4 .
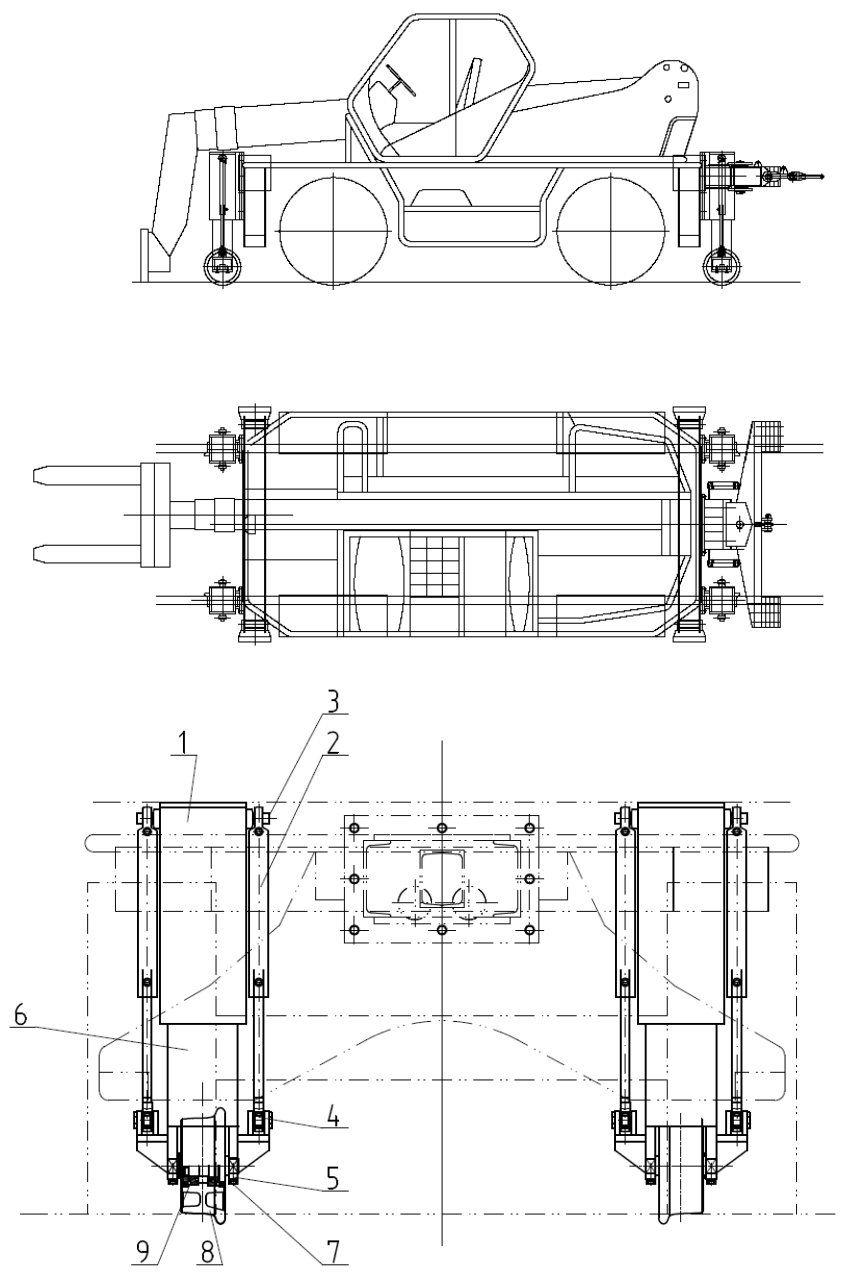

Rys. 4 Wariant III ładowarki szynowo drogowej

a) Widok $z$ boku

b) Widok $z$ góry

c) Widok z tyłu

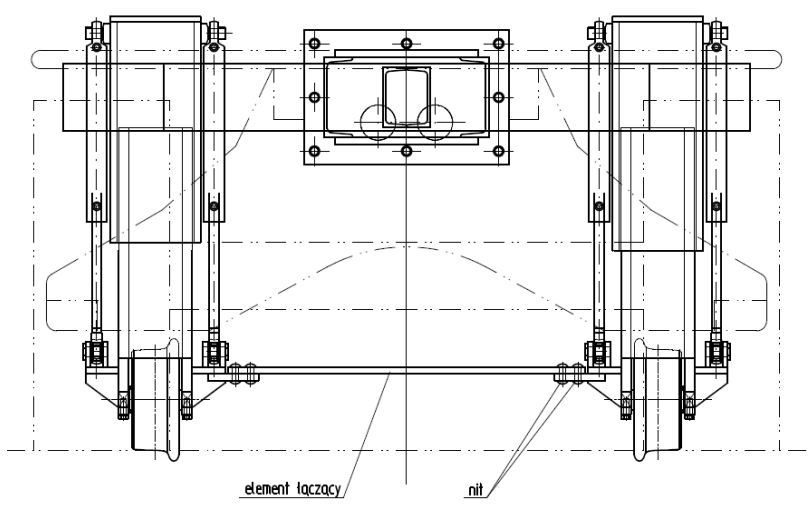

Rys. 5. Poprzeczne połączenie kolumn wewnętrznych

\subsection{Opis działania układów kolumnowych:}

Kolumnowy szynowy układ jezdny służy do poruszania się pojazdu po torze kolejowym. Zasilanie siłowników znajdujących się w kolumnach lub na zewnątrz kolumn jest sterowane $\mathrm{z}$ kabiny operatora $\mathrm{w}$ ten sposób, że dwie przednie kolumny sterowane są jednocześnie ( $\mathrm{z}$ jednego przycisku), a dwie tylne niezależnie (z oddzielnego przycisku).

W położeniu wyjściowym rolki są uniesione i pojazd jest przystosowany do poruszania się po drodze. Po ustawieniu pojazdu na torze i załączeniu ukła$\mathrm{du}$, rolki opuszczane są na szyny i stanowią prowadzenie dla pojazdu poruszającego się po torze. Pojazd jest napędzany od kół pojazdu. Ze względu na gabaryty pojazdu naruszające skrajnię w obrębie szyny należy unieść pojazd poprzez dalsze wysunięcie siłowników i przetoczenie pojazdu nad urządzeniami zabudowanymi przy szynach toru.

Z pośród omówionych wyżej układów najlepszym z punktu widzenia realizacji jest wariant III. Układ ten zapewnia stabilne podnoszenie rolki przy równomiernie rozłożonych naprężeniach. Istotną cechą tego układu są gabaryty kolumn, które w żaden sposób nie ograniczają zakresu prac wykonywanych przez ładowarkę. Pozostałe rozwiązania mniej lub bardziej ograniczają możliwości manewrowe wysięgnika. Szczególnie rozwiązanie II, ze względu na wysokość kolumn, które tworzą martwe pola w których nie można operować wysięgnikiem. Układy te moga jednak być z powodzeniem stosowane na innych urządzeniach, $\mathrm{w}$ tym również na ładowarkach MERLO np. typu ROTO 38.16, którego nieco inna budowa, w szczególności dłuższe ramię wysięgnika w stanie złożonym, pozwala na szerszą możliwość stosowania innych rozwiązań.

\section{Wprowadzone zmiany w pojeździe 4.1. Układ hydrauliczny}

Układ hydrauliczny (rys. 6) przeznaczony jest do opuszczania i podnoszenia rolek prowadzących. Do jazdy po torze rolki winny być opuszczone, natomiast do jazdy po drodze podniesione. Na panelu sterowania w kabinie znajdują się: przełącznik uruchamiający sterowanie elektryczne, zaworami $(1,2)$, cztery przyciski programowe sterujące blokiem rozdzielaczy podpór oraz przełącznik środkowy sterujący podnoszeniem lub opuszczaniem podpór i rolek. Układ hydrauliczny posiada zabudowane dwa bloki zaworowe: tylny i przedni.

W skład bloku zaworów sterujących tylnych wchodzą zdwojone elementy hydrauliczne: zaworów zwrotnych sterowanych (3), zaworów dławiących (4), przekaźników ciśnienia (5), manometrów (6) oraz zaworów odpowietrzających (11), przewidziane dla dwóch par niezależnie zasilanych cylindrów hydraulicznych (9). Blok zaworu przedniego składa się z 
tych samych elementów hydraulicznych co tylny lecz w ilości o połowę zmniejszonej, sterujący równocześnie czterema cylindrami hydraulicznymi.

W każdym bloku zaworowym zainstalowano układ z dwoma zaworami zwrotnymi sterowanymi (3). Zawory te pełnią rolę tzw. "zamków hydraulicznych", uniemożliwiających wypływ oleju z każdej części cylindrów przy neutralnym położeniu rozdzielacza podpór. Otwarcie zaworów jest możliwe w przypadku podania oleju do cylindrów od strony przeciwnej zaworu. Zabezpiecza to docisk rolek do szyn podczas jazdy pojazdu. Tylne cylindry posiadają zabudowane dwa układy zaworowe (3) zabezpieczające każdą parę cylindrów. Przednie cylindry wyposażono w jeden układ zaworowy umożliwiający przepływ oleju między cylindrami prawymi i lewymi dla zapewnienia stałego docisku rolek do toru podczas przejazdu przez tor wichrowaty. Każdy blok zaworowy wyposażony jest dodatkowo w przekaźnik ciśnienia (5), manometr (6) oraz odpowietrznik (11), odbierający i regulujący sygnał hydrauliczny od strony górnej komory pary cylindrów hydraulicznych. Regulując ciśnienie przekaźnika (5) dokonuje się jednocześnie odczytu wartości ciśnienia na manometrze pomiarowym (6). Sygnał hydrauliczny (ciśnienie) zamieniony zostaje w przekaźniku na sygnał elektryczny, który steruje odpowiednią cewką bloku rozdzielacza podpór (Y1-Y8) powodując automatyczne doładowanie lub obniżenie ciśnienia w górnej komorze cylindrów rolek jezdnych (9). Jest to tzw. automatyczny cykl pracy układu jezdnego, który załączany jest trzypołożeniowym przełącznikiem elektrycznym w kabinie koparki. Odpowietrzniki (11) pełnią rolę elementów jednocześnie odpowietrzających cylindry hydrauliczne podczas montażu lub przy wymianie oleju oraz służących do awaryjnego podniesienia rolek podczas zablokowania się sekcji rozdzielacza lub zaworów zwrotnych sterowanych.

Pomiędzy blokiem rozdzielaczy podpór (cewki Y1-Y8) a cylindrami hydraulicznymi podpór zabudowano bloki zaworów przełączających $(1,2)$. $\mathrm{Z}$ dwóch zaworów w bloku jeden zamyka zasilanie cylindra podpory (np.:2) drugi otwiera zasilanie cylindra rolki (np.:1). Z tyłu pojazdu znajdują się dwa identyczne bloki dwu zaworowe (cewki Y9 i Y10) oraz (cewki Y11 i Y12). Z przodu pojazdu znajduje się jeden blok dwu zaworowy (cewki Y13 i Y14) oraz jeden blok jedno zaworowy (cewkaY15), tylko odcinający jedną podporę.

Układ hydrauliczny sterownia pracą rolek jezdnych podłączany jest do istniejącej instalacji podpór koparki „Merlo” tak by w każdej chwili można było powrócić do pierwotnego rozwiązania, zmieniając tylko system podłączenia przewodów hydraulicznych, natomiast zachowując istniejące typy i długości przewodów.

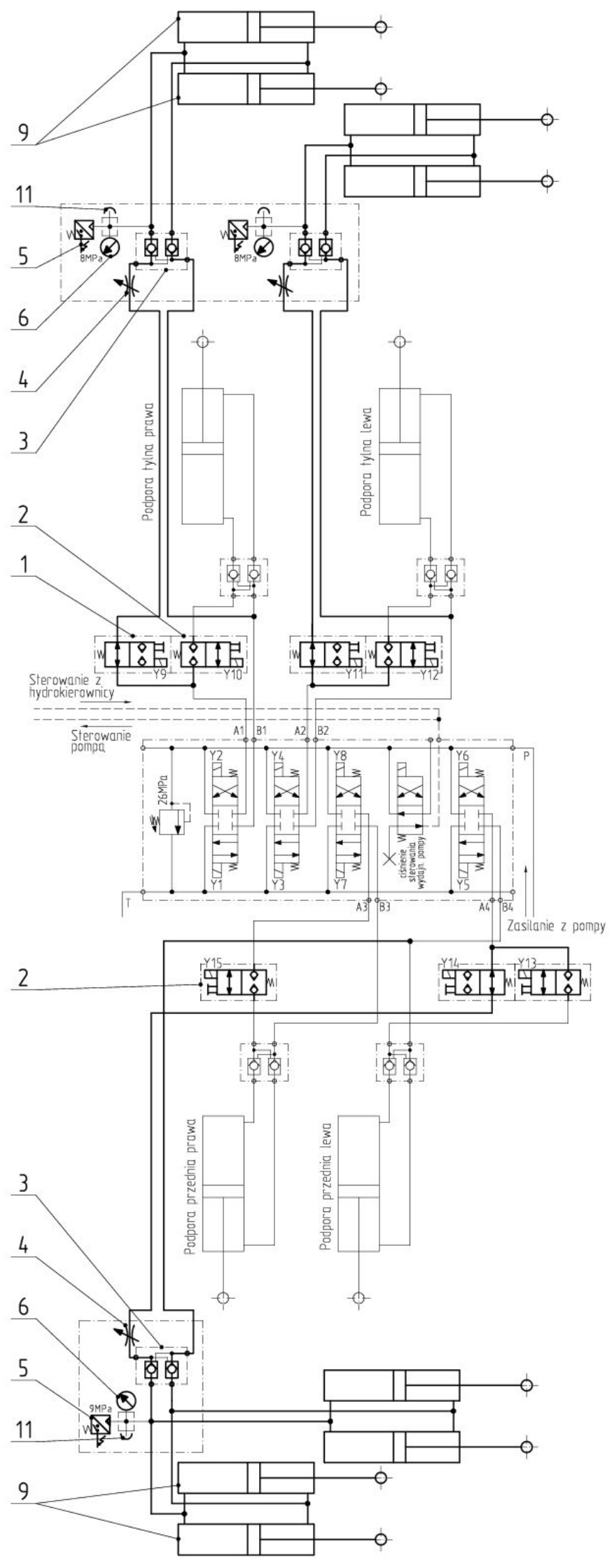

Rys.6 Schemat hydrauliczny sterowania rolkami jezdnymi. 
Blok zaworów tylnych (rys.7) ustala ciśnienie i reguluje wydatek oleju $\mathrm{w}$ dwóch parach cylindrów hydraulicznych poruszających dwoma kolumnami rolek jezdnych tylnych. Ciśnienie reguluje się dwoma przekaźnikami (3) ustalając wysokość położenia styków elektrycznych, zatem wielkość ciśnienia w cylindrach. Pomiar nastawionego ciśnienia można odczytać na manometrach (4). Wydatek oleju, zatem szybkość działania cylindrów ustala się regulowanymi dławikami (1). Każda para cylindrów posiada zabudowane w bloku zawory zwrotne sterowane (2), ustalające w sposób trwały każde dowolne położenie cylindrów. Każda komora górna pary cylindrów hydraulicznych połączona jest z zaworem odpowietrzającym (5), pozwalającym na odpowietrzenie lub awaryjne podniesienie rolek jezdnych. Wszystkie zawory i elementy regulacyjne montowane są do wspornika (6) i osłonięte osłoną (7) a całość przykręcona do spodniej części blachy pomostu koparki w obrębie lewego tylnego koła koparki.
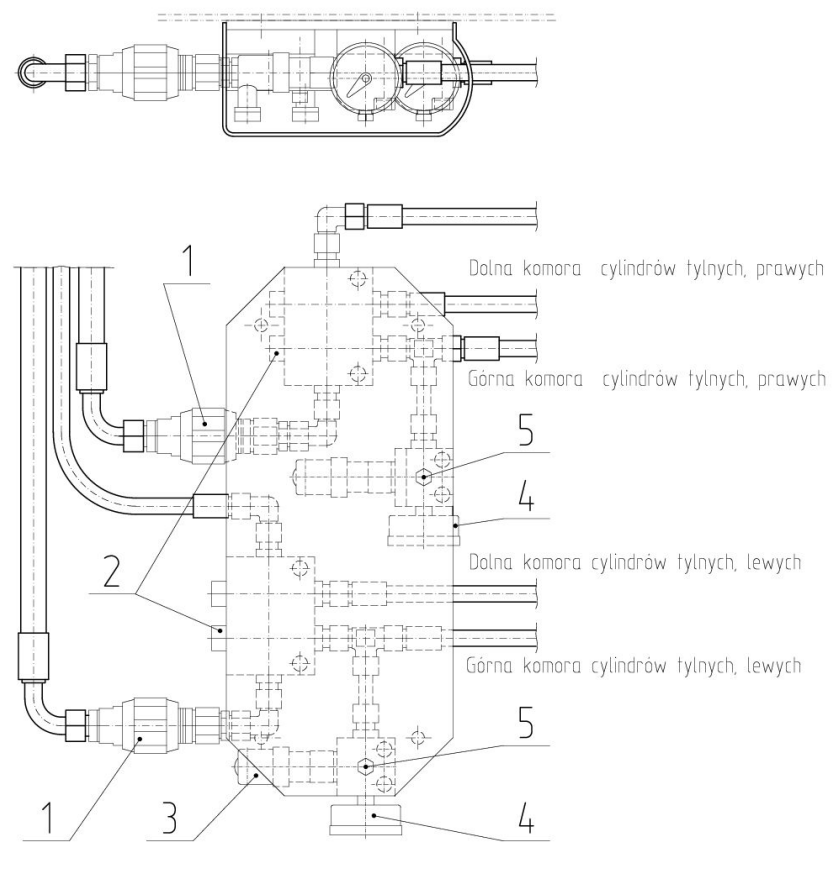

Rys.7 Blok zaworów sterujących cylindrami hydraulicznymi, tylnymi.

Blok zaworów przednich (rys.8) ustala ciśnienie i reguluje wydatek oleju $\mathrm{w}$ dwóch parach cylindrów hydraulicznych poruszających dwoma kolumnami rolek jezdnych przednich. Blok zbudowany jest identyczne jak blok zaworów tylnych lecz posiada o połowę mniej elementów hydraulicznych działających na tą samą ilość cylindrów hydraulicznych. Takie rozwiązanie bloku pozwala na zabezpieczenie równego docisku rolek przy wichrowatym torze. Cały blok przykręcony jest do spodniej części blachy pomostu koparki w obrębie lewego przedniego koła koparki.

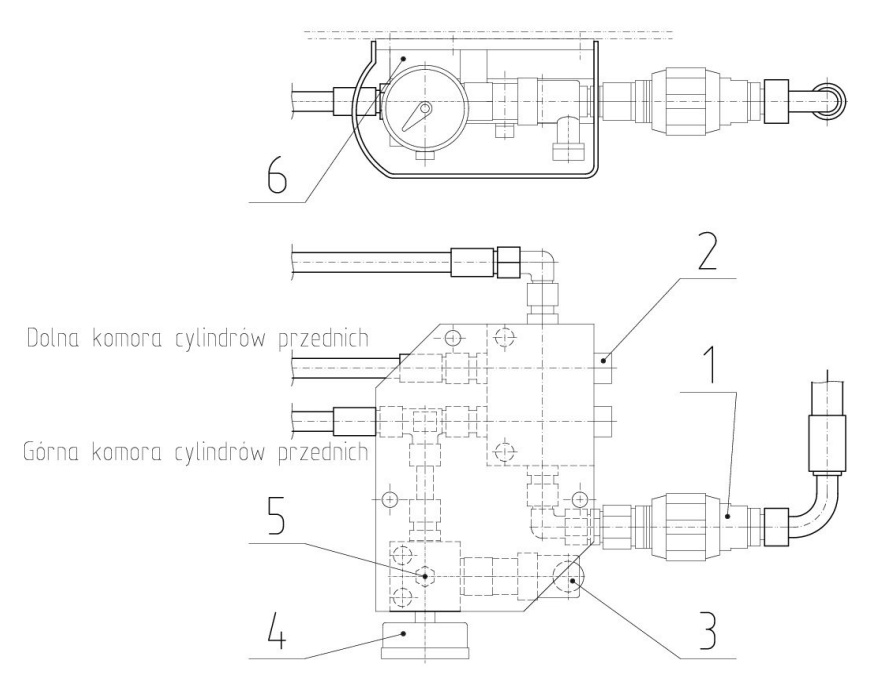

Rys.8 Blok zaworów sterujących cylindrami hydraulicznymi, przednimi.

Bloki zaworów odcinających montowane $\mathrm{z}$ tyłu pojazdu (rys.9a) składają się z: dwóch zaworów elektromagnetycznych (2) z cewkami (4) i wtyczkami elektrycznymi (3) połączonych ze sobą złączkami hydraulicznymi. Są przykręcone do wspornika (1). Bloki zaworów z tyłu pojazdu, lewy i prawy pełnią identyczną rolę, tj.: odcinają zasilanie $\mathrm{w}$ olej podpór tylnych oraz przełączają zasilanie do cylindrów hydraulicznych rolek jezdnych. Różnią się między sobą wykonaniem w lustrzanym odbiciu.

$\mathrm{Z}$ przodu pojazdu zamontowano: po lewej stronie blok zaworów tylnych prawych (lustrzane odbicie rys.9a) oraz po prawej stronie blok zaworu pojedyńczego (rys.9b). Blok zaworu przedniego prawego (rys.9b) pełni rolę zaworu tylko odcinającego zasilanie podpory przedniej prawej.
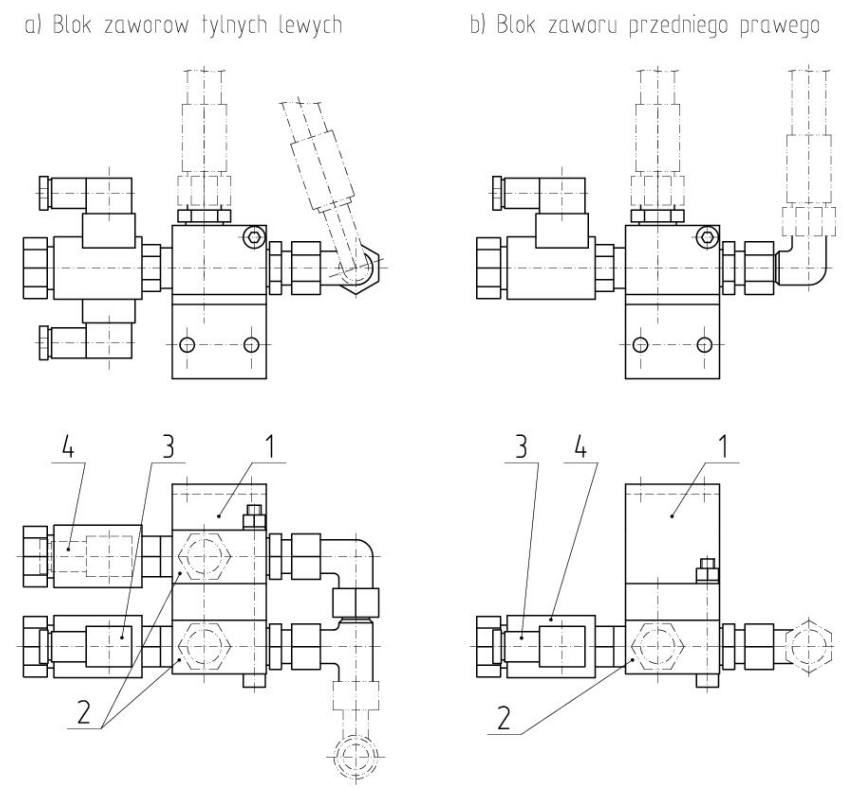

Rys.10 Bloki zaworów odcinających cylindry hydrauliczne podpór. 
Instalację elektryczną sterowania zespołami hydraulicznymi oparto na $12 \mathrm{~V}$ instalacji elektrycznej koparki. Poszczególne obwody elektryczne obejmują :

- obwód załączania napięcia sterowania rolkami,

- obwód podnoszenia i opuszczania rolek dla przodu i tyłu,

- obwód programu automatycznego sterowania dla przodu i tyłu pojazdu.

\subsection{Przykład konstrukcyjny zabudowy szynowego układu jezdnego na pojeździe}

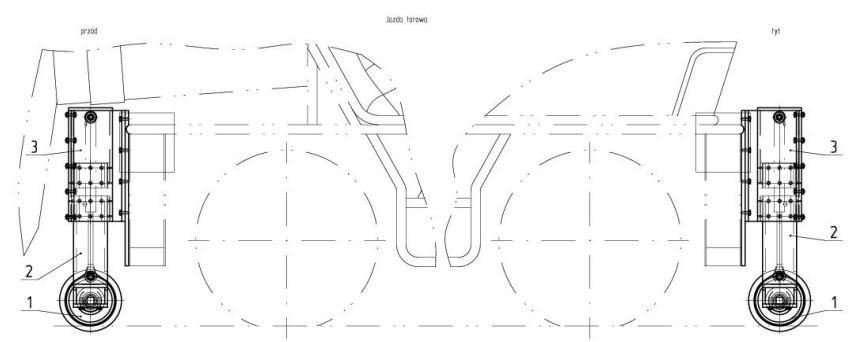

Rys. 10 Szynowy układ jezdny przedni i tylny

Szynowy układ jezdny (rys.10) zbudowany na pojeździe wyposażono w cztery zespoły kolumn prowadzących rolki jezdne. Dwie kolumny znajdują się z przodu pojazdu, natomiast dwie z tylu. Zespół kolumny składa się: z kolumny zewnętrznej (3) mocowanej do blachy montażowej przedniej i tylnej koparki, z kolumny wewnętrznej (2), wysuwanej dwoma cylindrami hydraulicznymi i połączonej z obrotowo zamocowaną rolką jezdną (1). Przemieszczanie pionowe rolek jezdnych odbywa się na drodze elektrohydraulicznej w cyklu ręcznym lub automatycznym z kabiny pojazdu.

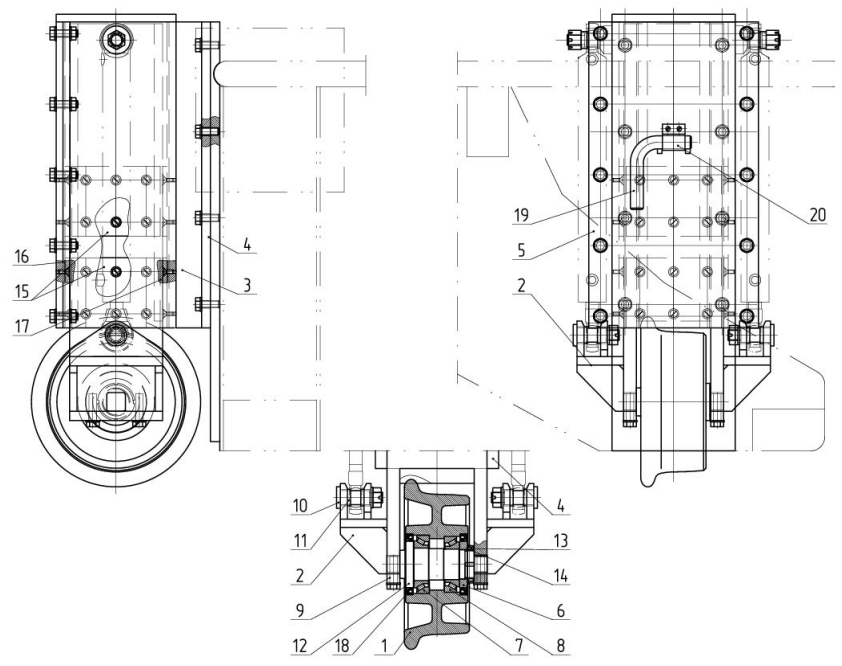

Rys. 11 Kolumna szynowego układu jezdr

Zespół kolumny (rys.11) składa się z: kolumny wewnętrznej (2) przemieszczającej się pionowo, wraz z rolką jezdną (1) względem kolumny stałej, zewnętrznej (3) przykręconej poprzez płytę mocująca (4) do ramy nośnej pojazdu. Ściana (5), przykręcona do kolumny zewnętrznej umożliwia demontaż kolumny wewnętrznej wraz ze ślizgami $(15,16,17) \mathrm{w}$ przypadku ich nadmiernego zużycia. W kolumnie wewnętrznej w jej dolnej części osadzona jest rolka (1). Rolkę kompletną demontuje się wraz z osią (12) i łożyskowaniem $(7,8)$ poprzez odkręcenie dwóch poprzeczek (9) i wysunięcie kwadratowych czopów osi (12) z prowadnic kolumny wewnętrznej. Kompletny zespół rolki składa się z: rolki (1) osadzonej na osi (12) poprzez łożyska stożkowe $(7,8)$ i uszczelnionej dwustronnie pierścieniami (18). Luzy montażowe łożysk reguluje się nakrętką (13) i podkładką zębatą (14).

Do sworzni górnych, przyspawanych do kolumny zewnętrznej (3) są mocowane dwa cylindry hydrauliczne. Ucha tłoczysk tych cylindrów są mocowane poprzez sworznie (10) i tulejki dystansowe (11) do wsporników kolumny wewnętrznej.

Każda kolumna jest wyposażona w specjalny sworzeń (19), który podczas pracy kolumny na torze jest osadzony w uchwycie (20). Podniesiona kolumna wewn. (2) w swym górnym położeniu winna być zabezpieczona sworzniem (19) przełożonym przez otwór i obróconym rękojeścią w dół.

\subsection{Urządzenie pociągowo zderzne}

Układ pociągowo - zderzny ma na celu umożliwienie ładowarce wykonywanie na torze lekkich prac manewrowych. Zabudowa sprzęgu zilustrowana jest na rysunku 12. W skład układu sprzęgającego wchodzi dwuczęściowy sprzęg haka pociągowego z uchem (8) i sworzniem mocującym. Sprzęg jest ręcznie zakładany na hak pociagowy wagonu przez manewrowego.

Sprzęg jest zabudowany na obrotowej belce zderzakowej (6). Belka obrotowa zapewnia płynny przejazd zestawu (ładowarka + wagon) przez łuki. Belka w stanie prostopadłym do osi wzdłużnej pojazdu utrzymywana jest przez sprężyny (4) po bokach belki. Na końcach belki są zamontowane gumowe amortyzatory zderzne (5).

Do jazdy drogowej należy sprzęg (8) zamocować w pozycji pionowej spinając swożniem dwa ucha (ucho sprzęgu $\mathrm{z}$ uchem belki zderznej).

Sprzęg haka pociagowego (8) z belką zderzakową (6) jest mocowany do wspornika belki (7) obrotowo przy pomocy sworznia (3). Wysokość położenia belki zderzakowej jest regulowana podkładkami (2). Wspornik belki zderzakowej (7) jest przykręcony śrubami do płyty mocującej (1).

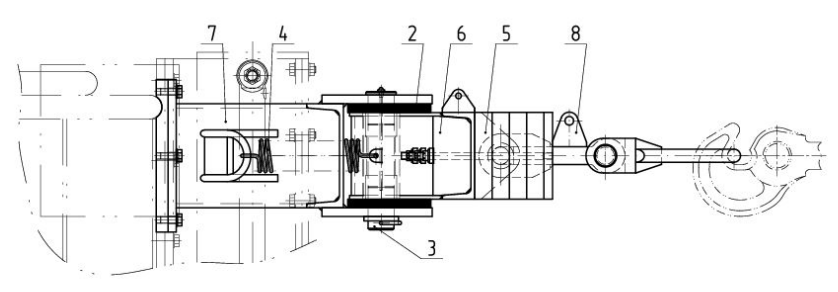




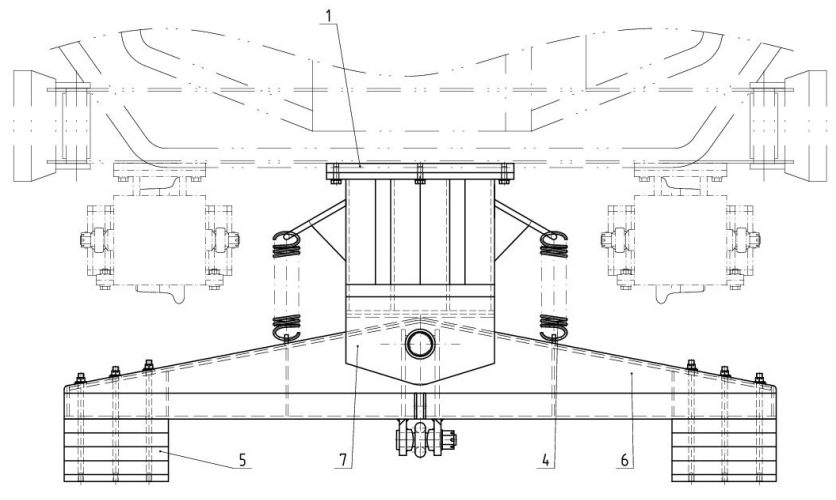

Rys.12 Zabudowa sprzęgu

\section{Podsumowanie}

Ładowarka szynowo - drogowa MERLO jest nowatorskim rozwiązaniem $\mathrm{w}$ katalogu pojazdów mogących poruszać się po torach kolejowych. Stanowi przykład rozszerzania możliwości eksploatacyjnych pojazdów drogowych i nowatorskiego podejścia, nie zawsze zgodnego z ich pierwotnym wykorzystaniem. Ilustruje również istniejącą na polskim rynku dziedzinę pojazdów szynowo - drogowych oraz różnorodne możliwości praktycznego zastosowania.
Obecnie zaprojektowane i wyprodukowane pojazdy szynowo - drogowe w Polsce są wykonywane na bazie seryjnie produkowanych pojazdów drogowych, które w swoim pierwotnym założeniu nie były przystosowane do poruszania się po torach kolejowych. Powstałe w ten sposób konstrukcje nastręczają wiele trudności na etapie projektowym. Docelowym rozwiązaniem winno być tworzenie pojazdów szynowo - drogowych od podstaw. Takie rozwiązanie umożliwi najlepszy dobór parametrów i daje możliwość zastosowania najlepszych rozwiązań konstrukcyjnych szynowego układu jezdnego.

Prezentowane rozwiązania techniczne szynowego układu jezdnego są przedmiotem zgłoszenia patentowego.

\section{Literatura:}

[1] Marciniak Z., Medwid M.: Pojazdy szynowodrogowe. Ośrodek Badawczo Rozwojowy Pojazdów Szynowych. Poznań 1999.

[2] Medwid M.: Pojazdy szynowo-drogowe polskiej konstrukcji. Przeglad Mechaniczny nr 5-6/93r.

[3] Medwid M., Pohl K.: Pojazd szynowo drogowy UNISTAR dla ratownictwa technicznego przystosowany do jazdy po torach tramwajowych. Pojazdy Szynowe 2/98r.

[4] Medwid M.: Przyktad zastosowania pojazdu szynowo-drogowego w stuzbach budowy i utrzymania infrastruktury kolejowej PKP. Pojazdy Szynowe 4/02r.

[5] Medwid M., Sienicki A.: Pojazd szynowo-drogowy z bębnowym napędem ciernym szynowego układu jezdnego. Pojazdy Szynowe 1/03r.

[6] Medwid M., Przepióra K.: Pojazdy szynowo drogowe o różnych przeznaczeniach. Konferencja NOT Innowacje dla przedsiębiorstw. Poznań, listopad $2004 r$. 